\title{
Does Fish Conditioning in Aquaculture Increase Survival Success in the Wild? A Case Study on a Cyprinid Fish
}

\author{
Marek Šmejkal ${ }^{1, *(D)}$, Daniel Bartoň ${ }^{1,2}$, Petr Blabolil ${ }^{1,2}$, Peter Podhorec ${ }^{3}$, Allan T. Souza ${ }^{1}$, Vlastimil Stejskal ${ }^{3}$ (D), \\ Yevdokiia Stepanyshyna ${ }^{1}$ and Sandip Tapkir ${ }^{1}$ \\ 1 Biology Centre of the Czech Academy of Sciences, Institute of Hydrobiology, 37005 České Budějovice, \\ Czech Republic; daniel.barton@hbu.cas.cz (D.B.); petr.blabolil@hbu.cas.cz (P.B.); \\ allan.souza@hbu.cas.cz (A.T.S.); step.yevdokiya@seznam.cz (Y.S.); sandip.tapkir@hbu.cas.cz (S.T.) \\ 2 Faculty of Science, University of South Bohemia, 37005 České Budějovice, Czech Republic \\ 3 South Bohemian Research Center of Aquaculture and Biodiversity of Hydrocenoses, Faculty of Fisheries and \\ Protection of Waters, Institute of Aquaculture and Protection of Waters, University of South Bohemia in České \\ Budějovice, Na Sádkách 1780, 37005 České Budějovice, Czech Republic; podhorec.peter@seznam.cz (P.P.); \\ stejskal@frov.jcu.cz (V.S.) \\ * Correspondence: marek.smejkal@hbu.cas.cz
}

check for updates

Citation: Šmejkal, M.; Bartoň, D.; Blabolil, P.; Podhorec, P.; Souza, A.T.; Stejskal, V.; Stepanyshyna, Y.; Tapkir, S. Does Fish Conditioning in Aquaculture Increase Survival Success in the Wild? A Case Study on a Cyprinid Fish. Sustainability 2021, 13, 13936. https://doi.org/10.3390/ su132413936

Academic Editor: Tim Gray

Received: 10 November 2021 Accepted: 13 December 2021 Published: 16 December 2021

Publisher's Note: MDPI stays neutral with regard to jurisdictional claims in published maps and institutional affiliations.

Copyright: (C) 2021 by the authors. Licensee MDPI, Basel, Switzerland. This article is an open access article distributed under the terms and conditions of the Creative Commons Attribution (CC BY) license (https:// creativecommons.org/licenses/by/ $4.0 /)$.

\begin{abstract}
Many endangered fish species in the wild are artificially bred, and their populations are strengthened by the stocking of aquaculture-raised juveniles. Because fish from aquaculture are generally not well prepared for the challenging life in the wild, we tested whether training for selected challenges could improve fish survival after stocking. We chose conditioning on predation pressure (by learning predator image of northern pike Esox lucius using predator chemical cues and visual stimuli), increased rearing water velocity $20 \mathrm{~cm} \times \mathrm{s}^{-1}$, and direct exposure to predation. The juvenile cyprinid fish asp (Leuciscus aspius) was used as a model prey species. A total of 7949 asp were reared in four groups using a combination of high flow, predation, and control treatments (low flow, no predation; 2018, 2149, 1929, and 1856 individuals, respectively). Of these, 1800 individuals were released into three ponds with pike, and their mortality rates were monitored in relation to predation for two months after stocking using passive telemetry arrays. The remaining 6149 aquaculture-reared individuals were released directly into a large reservoir, while 1426 individuals that survived pike predation for two months were released after the pond experiment ended. Fish survival in a reservoir was monitored in 2020 and 2021 by boat electrofishing and passive telemetry. The effect of training in aquaculture was not detected in pond conditions, but the fish that survived direct predation from pike for two months in the semi-natural treatment were more likely to survive in the wild than their aquaculture-reared counterparts. In the laboratory environment, asp responded to predator chemical cues with an increase in shoal cohesion and swimming activity, which demonstrate their ability to detect chemical cues. However, exposure to more fluvial conditions did not result in increased critical swimming speed. The study suggests that conditioning tested in aquaculture may not be sufficient to prepare fish for the wild, while exposing fish to direct predation could increase fish survival.
\end{abstract}

Keywords: stocking efficiency; swimming capacity; chemical cues; electrofishing; behavior; Leuciscus aspius

\section{Introduction}

Populations of many fish species are declining worldwide [1-3]. The reasons for declining fish populations are diverse, ranging from habitat alteration to invasions of non-native species [4-7]. In the freshwater environment, migratory rheophilic fish species are a particularly threatened group [8-10]. It is common practice to strengthen threatened populations by artificially rearing and stocking (raising fish in a rearing facility and transfer to a novel environment) individuals of various sizes to maintain fish stocks (population 
size) or improve yields of target species [11-13]. However, fish in aquaculture are predominantly reared in conditions that are very different from the environment intended for their release [14]. Therefore, their experience with predators and their appropriate reactions to them are weaker than in wild populations [15-17]. However, the effects of exposing fish to relevant stimuli in the rearing facility on survival in the wild are not fully understood (but see [18]).

Predation is one of the shaping forces that exerts high selective pressure on the individual's success in survival until reproduction [19]. Fish reared in aquaculture are in the majority free of predation due to emphasis in aquaculture on high yield (except carnivorous fish breeding programs with the presence of cannibalistic individuals). Therefore, hatcheryreared fish are naive to most predators they encounter after stocking [20-22]. The sudden encounter with a predator is therefore a novel experience, and it can be fatal within a very short time after fish release $[23,24]$. However, it is possible to prepare the fish for an encounter with a predator in the rearing facility. Fish may associate danger with novel species by perceiving chemical cues released by injured conspecifics, or chemical cues released by a predator that has eaten a conspecific (termed predator chemical cues) $[25,26]$. The danger associated with the image of the predator then alerts prey encountering the predator in the wild, and such prey has a higher chance of avoiding an attack by the predator than naïve prey [27-29]. Therefore, such treatment in aquaculture should reduce the mortality rate due to predation with little additional effort. Alternatively, fish can be exposed to direct predation pressure under controlled conditions (if ethically permissible in the country), allowing prey to learn predator avoidance mechanisms. However, such treatment is not loss-free, but individual chances of survival after stocking may be improved [30].

Foraging in the wild is more demanding than in aquaculture. While fish farmed in aquaculture do not have to search intensively for food, in the natural environment they have to travel long distances to find a similar amount of natural food sources [31-33]. This leads to morphological and behavioral differences between wild and aquacultured fish [34]. Aquacultured fish have been found to have shorter fins relative to body length than their native counterparts due to fin erosion [35-37], and the size of the caudal fin may subsequently affect the burst swimming speed when encountering predators [38,39]. In addition, aquaculture fish are characterized by a bolder behavioral syndrome during food competition than their wild counterparts and are slower in responding to predator attacks $[40,41]$. Boldness is generally associated with a higher encounter rate with predators and insufficient flexibility in feeding behavior $[17,42,43]$. Therefore, better preparation for the challenging environment should potentially reduce mortality risk. The additional cost of rearing may be compensated or ideally surpassed by a higher survival rate of fish reared in aquaculture [29].

Fish size and condition are important for stocking. Larger fish size and good condition seem to increase the probability of stocking success [44]. The fish condition factor is an essential parameter for stocking success, especially due to the frequent deterioration of fish condition after stocking related to slow adaptation to different food sources in the wild $[42,45]$. Therefore, these parameters seem to be crucial when preparing fish for stocking.

In this study, we used asp (Leuciscus aspius as model species) to test whether conditioning to predation and water flow improved the stocking success. Specifically, we reared 7949 fish under four conditions (standing water and no predator chemical cues, standing water and weekly introduction of predator chemical cues along with a model predator-northern pike (Esox lucius) - fluvial water and no predator chemical cues, and fluvial water and weekly introduction of predator chemical cues along with northern pike. Fish survival was assessed in three ponds and a large reservoir. Fish were stocked in a reservoir either directly from aquaculture or from the two-month-long pond experiment with northern pike direct predation. We expected that (i) fish exposed to predator conditioning treatment will have better survival than the control treatment group, (ii) fish conditioned for better swimming capacity will handle the shift from aquaculture to wild 
better due to their assumed improved locomotive ability, resulting in the higher survival rate of stocked fish, and (iii) fish exposed to direct predation by northern pike in pond experiment will more likely survive in the reservoir than the fish transported to reservoir directly from aquaculture.

\section{Materials and Methods}

\subsection{Species Description}

Asp is a cyprinid fish that shifts from invertebrate to fish feeder through its ontogeny. At the usual stocking size of asp (7-10 cm total length), invertebrate food sources dominate its diet $[46,47]$. Asp inhabits primarily fluvial environments and, to a lesser extent, lacustrine environments. They can thrive in the lacustrine environment provided that it is connected to a riverine system to ensure successful reproduction $[48,49]$. This species is protected in selected areas of the European Union under the Habitats Directive, and in some protected areas included in the NATURA 2000, the population is maintained by capturing adult fish and artificially spawning and rearing them to the stocking size [50].

\subsection{Fish Origin and Ethical Statement}

The experimental procedures were performed under guidelines of the European Communities Directive (No. 2010/63/EU) on the protection of animals used for scientific purposes and have been approved by the Czech Ministry of Health (MSMT-7577/2019-2) and the sampling permission from the Ministry of Environment of the Czech Republic (OZPZ 201/2019 Vac/3). The fish were the offspring of 40 wild-caught asp from Želivka Reservoir ( $49^{\circ} 72^{\prime} 50^{\prime \prime} \mathrm{N}, 15^{\circ} 08^{\prime} 94^{\prime \prime}$ E, $1602 \mathrm{ha}$ ), Czech Republic. Juvenile asp were obtained from an artificial breeding program supporting asp stock (Biofish s.r.o., Pravíkov, Czech Republic) and transported in polyethylene bags with oxygen atmosphere to the Research Institute of Fish Culture and Hydrobiology (České Budějovice, Czech Republic).

\subsection{Rearing of Asp Juveniles in Intensive Conditions}

The conditioning of juvenile asp was done in two phases with two different objectives. Firstly, fish were transported on 10 October 2019 to prepare them for the pond mesocosm experiment and release in Želivka Reservoir (method description below), where the fish survival was evaluated. Secondly, fish were purchased on 3 March 2021 to prepare them with identical methodology and test in the laboratory conditions, how they differ in their swimming capacity, and whether asp reacts to predator chemical cues.

Fish were acclimated for two weeks in the experimental facility and were slowly accustomed to feed on a commercial diet Skretting Gemma Diamond $1.8 \mathrm{~mm}$ (Stavanger, Norway; proteins $57 \%$, lipids $15 \%$, ash $10 \%$, fibre $0.2 \%$, P $1.5 \%$, Ca $2.5 \%$, Na $0.6 \%$.). A mixture (Chironomus sp.) of frozen bloodworms and a commercial pellet diet was offered 14 days after transport, and the proportion of pellets was gradually increased to $100 \%$.

After the adaptation period, juveniles raised for mesocosm and stocking experiment were placed in rectangular $590 \mathrm{~L}$ plastic tanks at density of 1.7 individuals. $\mathrm{L}^{-1}$ (1000 individuals per tank). The recirculating system with a total water volume of 13,300 L managed eight and four fish tanks, respectively. Juveniles raised for laboratory testing were kept in four tanks at density 0.5 individuals. $\mathrm{L}^{-1}$ (275 fish per tank). The experimental system was equipped with mechanical drum filter AEM 15 (AEM-Products V.O.F., Lienden, The Netherlands) three sump tanks (1000 L each) with a series of filtration sections, Bioakvacit PP10 (Jezírka Banát s.r.o., Hněvotín, Czech Republic), a moving bed biofilter (three sections, 1800 L each) with media BT10 (Ratz Aqua \& Polymer Technik, Remscheid, Germany), and an Eheim Jäger Thermocontrol 300 flow-through heater (Eheim GmbH \& Co KG, Stuttgart, Germany) incorporated directly into the recirculation flow. The basal flow rate in each

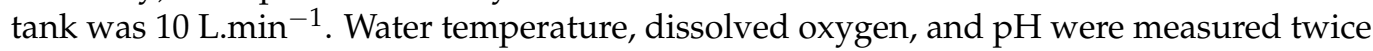
daily using a combined $\mathrm{pH}$ and oxygen meter (MultiLine P4, WTW, Weilheim, Germany). Nitrite, ammonium, and phosphate levels were measured every three days. Water quality was maintained at the following values (mean \pm S.D., $\mathrm{T}=20.1 \pm 3.24^{\circ} \mathrm{C} ; \mathrm{pH}=7.0 \pm 0.5$; 
oxygen saturation $=90.1 \pm 7.2 \%, \mathrm{NH}_{4}{ }^{+}=0.77 \pm 0.35 \mathrm{mg} / \mathrm{L} ; \mathrm{NH}_{3}{ }^{-}=0.004 \pm 0.004 \mathrm{mg} / \mathrm{L}$; $\left.\mathrm{NO}_{2}{ }^{-}=0.17 \pm 0.14 \mathrm{mg} / \mathrm{L}\right)$. The culture room was kept at a light intensity of $139 \pm 15 \mathrm{Lx}$ on a water surface with a light regime of $12 \mathrm{~h}$ light (07:00 a.m. to 07:00 p.m.) and $12 \mathrm{~h}$ dark (07:00 p.m. to 07:00 a.m.). Fish were fed daily at 9:00 a.m., 11:00 a.m., and 03:00 p.m. with the same commercial pellets as during the acclimation period.

After conditioning, fish were anesthetized with MS-222 and individually tagged with a passive integrated transponder tag (PIT tag, Oregon RFID, half-duplex, length $23 \mathrm{~mm}$, diameter $3.65 \mathrm{~mm}$, weight $0.8 \mathrm{~g}$, ISO 11784/11785 compatible) from 4 to 7 May 2020 and 3 March 2021, respectively. Three to four scales were removed above the ventral fin and a vertical incision approximately $4 \mathrm{~mm}$ long was conducted to allow insertion of a PIT tag into the body peritoneum cavity. Because sutures have been found to have negative effects on fish health after PIT tagging process, no sutures were used to close the incision [51,52]. Standard length (SL in mm), weight (g) and PIT-tag identification code were recorded for each individual. The size of the PIT tags was chosen based on the desired performance in the passive telemetry experiment. Due to the relatively large ratio between PIT tag and fish size potentially affecting fish feeding and overall performance [53], fish were given two to three weeks after surgery to recover before the experiments began. Fish reared for the field experiments were left for two (large field experiment) or three (semi-natural experiment) more weeks in the tanks and the training conditions continued until their release into pond mesocosms or reservoir (details below). Fish for the laboratory experiments were tagged three weeks prior to their training to track the progress of each animal in the conditioning procedure.

\subsection{Fish Exposure to Increased Water Velocity and Predator Cues}

Four experimental groups were established and exposed to the conditions described below for two months (1 March to 1 May, 2020 for the pond mesocosm and reservoir experiment, 1 May to 1 July, 2021 for the laboratory tests; Figure 1). These groups included a control group (Standing Water + No Cues SWNC), in which no manipulation was performed with water velocity and predator chemical cues. The second group (Standing Water + Cues SWC) was treated by the presence of a predator (northern pike, $1 \mathrm{~h} /$ week and addition $10 \mathrm{~L}$ of water with predator chemical cues, see below for details). The third group (Fluvial Water + No Cues FWNC) was exposed to increased water velocity without the presence of the predator and its chemical cues. Finally, the fourth group (Fluvial Water + Cues FWC) was exposed to fluvial water conditions and the presence of a predator and its chemical cues. Numbers of conditioned fish per treatment were SWNC:2149, SWC:1856, FWNC: 2018 and FWC: 1929 for stocking and 275 individuals per treatment for laboratory testing.

Prior to the main experimental phase, four individuals of northern pike (SL $45-55 \mathrm{~cm}$, weight $650-950 \mathrm{~g}$ ) were transported to the laboratory for the production of predator chemical cues. Three additional tanks of size $180 \times 120 \times 77 \mathrm{~cm}$ were used for keeping the northern pike. Predator chemical cues were obtained by holding northern pike in plastic tanks $(50 \mathrm{~L})$ for $24 \mathrm{~h}$. Two asp treatment groups assigned to the predator treatment were treated according to the following protocol: during the learning predator recognition in the predation treatments, $10 \mathrm{~L}$ of water was added to experimental tanks along with the predator northern pike placed in the plastic cage (size $50 \times 30 \times 23 \mathrm{~cm}$ ) with a mesh size of $5 \mathrm{~mm}$. This treatment was repeated weekly, resulting in nine replicates throughout the training period. The northern pike was kept in similar tanks and fed daily with a juvenile asp $(125 \pm 5 \mathrm{~mm}$ and $16.1 \pm 5.0 \mathrm{~g})$. 


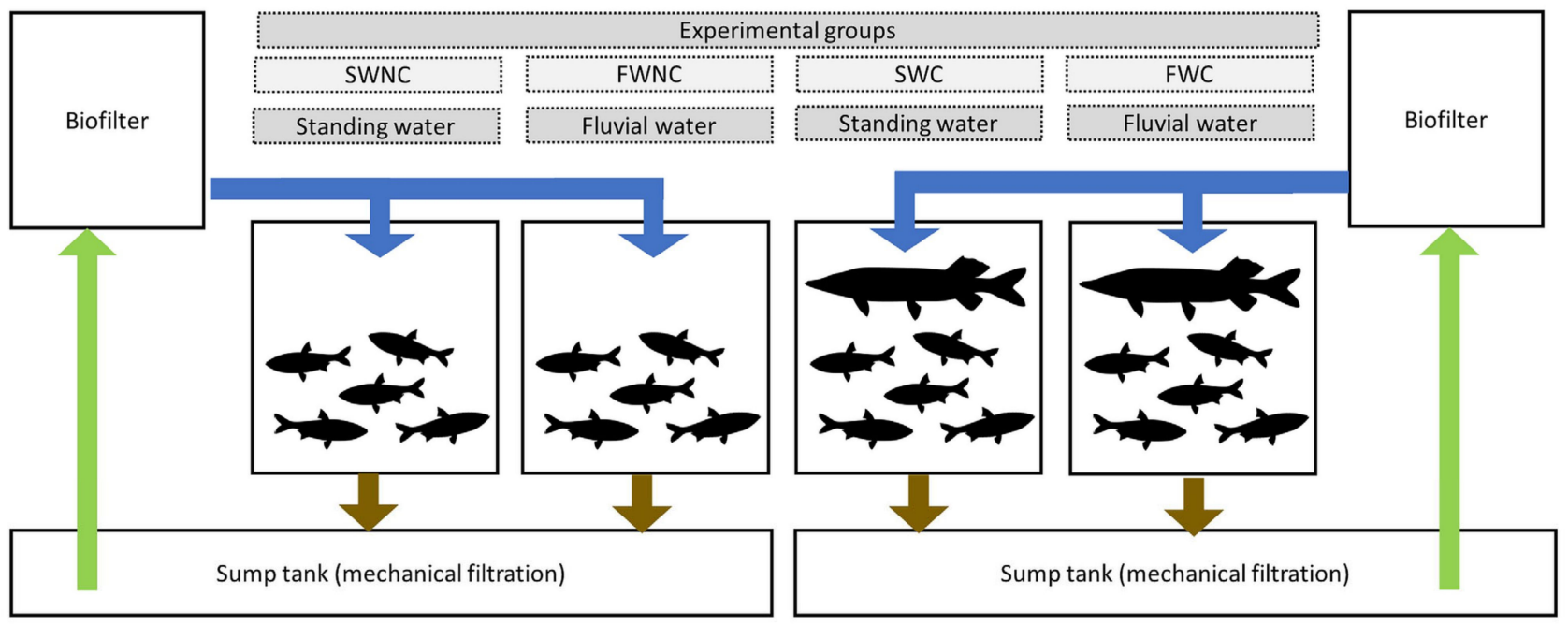

Figure 1. Scheme of treatment groups in the experiment prepared in aquaculture for the four conditions (SWNC-standing water and no cues; FWNC-fluvial water and no cues; SWC-standing water and chemical cues; FWC-fluvial water and chemical cues). The recirculation system was designed to avoid mixing predator chemical cues in with the control treatments. Two tanks per treatment were used in conditioning for stocking and one tank per treatment was used in conditioning for laboratory testing.

All experimental tanks containing asp were equally supplied with recirculated water $\left(0.16 \mathrm{~L} \times \mathrm{sec}^{-1}\right)$. High water velocity in the flowing water treatment conditions was created by two jet pumps (Jebao ATI SOW-15; 15,000 L $\times$ hour $^{-1}$ ). A handheld vane wheel flow meter (Höntzsch GmbH \& Co. KG, Waiblingen, Germany) was used to measure water velocity in the tanks as well as for calibration of swimming tunnels. Average water velocity was $18.8 \pm 18.7 \mathrm{~cm} \times \mathrm{s}^{-1}$ for groups with water velocity manipulation (FWNC, FWC) and $1.9 \pm 1.3 \mathrm{~cm} \times \mathrm{s}^{-1}$ for groups without water velocity manipulation (SWNC, SWC). These water velocities correspond to $1.66 \pm 1.65$ body length $\mathrm{BL} \times \mathrm{s}^{-1}$ and $1.38 \pm 1.37 \mathrm{BL} \times \mathrm{s}^{-1}$, respectively, at the termination of the experiment in the FWNC and FWC treatment groups. In SWNC and SWC groups, water velocities correspond to $0.16 \pm 0.11\left(\mathrm{BL} \times \mathrm{s}^{-1}\right)$ at the start and $0.14 \pm 0.09 \mathrm{BL} \times \mathrm{s}^{-1}$ at the termination of the experiment.

The same experimental recirculating aquaculture system was divided into two equal systems to avoid the effects of predator cues in FWNC and SWNC treatment groups. Each system consists of two rearing tanks (590 L), mechanical drum filter AEM 15 (AEMProducts V.O.F., Lienden, The Netherlands) a tank (1000 L) with a series of filtration sections (Bioakvacit PP10; Jezírka Banát s.r.o., Hněvotín, Czech Republic), a moving bed biofilter (1800 L) with BT10 media (Ratz Aqua \& Polymer Technik, Remscheid, Germany), and an Eheim Jäger Thermocontrol 300 flow-through heater (Eheim GmbH \& Co KG, Stuttgart, Germany). Water quality was maintained at the following levels during this phase (mean \pm S.D., $\mathrm{T}=16.4 \pm 0.9^{\circ} \mathrm{C} ; \mathrm{pH}=7.3 \pm 0.3$; oxygen saturation $=89.1 \pm 6.2 \%, \mathrm{NH}_{4}{ }^{+}=$ $\left.0.76 \pm 0.34 \mathrm{mg} \times \mathrm{L}^{-1} ; \mathrm{NH}_{3}{ }^{-}=0.010 \pm 0.004 \mathrm{mg} \times \mathrm{L}^{-1} ; \mathrm{NO}_{2}{ }^{-}=0.19 \pm 0.13 \mathrm{mg} \times \mathrm{L}^{-1}\right)$.

The number of individuals reared for the pond mesocosm experiment and the largescale experiment was SWNC: 2149, SWC: 1856, FWNC: 2018, and FWC: 1929. The total number of PIT tagged and conditioned fish for the laboratory tests was 150, from which were fish randomly selected for the two experiments described below.

\subsection{Pond Mesocosm Experiment}

The experiment was conducted in the Vodñany ponds (49.155524 N, $14.164678 \mathrm{E}$, Czech Republic), where each of the three ponds $(20 \times 30 \mathrm{~m}$ with average depth $60-85 \mathrm{~cm})$ was evenly stocked with 1800 asp (150 individuals from the four treatment groups in each pond). Survival of individually tagged fish at the ponds was tracked by passive telemetry systems. The passive telemetry system consisting of a single antenna loop $(4 \times 1 \mathrm{~m}$, LF HDX RFID readers) in each pond was used to evaluate the mortality of each group. Each 
pond was divided into two parts by a barrier, and fish had to swim through the telemetry antenna as they crossed the pond from one side to the other. The charging and recording frequency were set to 10 energize cycles $\mathrm{s}^{-1}$. The individual code was recorded when the tagged fish passed the antenna loop and stored along with a timestamp. Northern pike was introduced on 29 May 2020 with 4 to 6 individuals in each pond and average total biomass of $3.7 \pm 1.1 \mathrm{~kg}$ (mean \pm standard deviation). The monitoring and sampling started 29 May 2020 and was terminated on 29 July 2020. The ponds were fished out by draining in 29 July 2020. The remaining living asp (1426, $79.2 \%$ of the initial) were measured, weighed, scanned for PIT tags and transported to the Želivka Reservoir immediately after the termination of the experiment. Growth increment (SL) was calculated for each surviving individual.

Detections of individual tags in ponds were summarized by week and group category in each pond separately. If the tag was not detected in one week and was detected at a later time or the fish was caught at the end of the experiment, its survival was backfilled in the data set.

\subsection{Reservoir Stocking Experiment}

The 6149 individuals were released in the Želivka Reservoir on 19 May 2020, and the remaining 1426 asp from semi-natural experiment trained on northern pike direct predation were released on 29 July 2020 (7575 individuals in total). The study site has the largest population of asp in the country and is protected by Natura 2000 [7]. The shoreline of Želivka Reservoir was sampled with an electrofishing boat (electrofisher EL 65 II GL DC, Hans Grassel, Schönau am Königsee, Germany, 13 kW, used voltage and current 500 V, 10 A, pulsed DC, frequency $70 \times \mathrm{s}^{-1}$ ) in 24-26 August 2020, on 18 March to 25 April 2021 during the spring spawning migration of asp [48] and on 25-27 August 2021 (Figure 2). The boat has approximately a six-meter-wide and a three-meter-deep energized field. Paralyzed individuals were placed in the aerated vat and when the fish sampling was completed at a specific location, asp were immediately scanned for potential PIT tags, measured and released back into the reservoir after recovery. During the 2021 spring season (18 March to 6 May), three antenna arrays (antenna loop size 10-18 $\times 0.6 \mathrm{~m}$, LF HDX RFID readers) were installed in the tributary as an additional tool to detect surviving fish aside from electrofishing (details in [48]) and the PIT tag detections were used as a sign of fish survival.

\subsection{Laboratory Assays on Conditioned Fish}

Fish were conditioned in the four treatment groups (SWNC, SWC, FWNC, FWC) according to the protocol described above (Figure 3). After two months of conditioning, fish were subjected to two tests: (i) swimming speed capacity and (ii) reaction to predator chemical cues to determine the effects of training under aquaculture conditions on fish behavior.

\subsubsection{Measurement of Critical Swimming Speed, Oxygen Consumption, and Cost of Transport}

At the start and termination of the experiment, the swimming performance of the juveniles was evaluated in a $10 \mathrm{~L} 40 \times 10 \times 10 \mathrm{~cm}$ Steffensen type swimming tunnel respirometer (Loligo systems, Tjele, Viborg, Denmark). The swim tunnel was submerged in a buffer tank connected to an aerated temperature-controlled $100 \mathrm{~L}$ reservoir tank that provided continuous water exchange. The swimming tunnel was connected to the buffer tank via a flush pump $\left(20 \mathrm{~L} \times \mathrm{min}^{-1}\right.$, Eheim $\mathrm{GmbH}$, Deizisau, Germany) to provide water with a sufficient dissolved oxygen concentration. A fibreoptic oxygen probe and a temperature probe connected to a Witrox 1 (Loligo Systems, Tjele, Viborg, Denmark) were used to continuously record dissolved oxygen and temperature in the swimming tunnel. The swimming tunnel itself was connected to AutoResp@) software (Loligo Systems, Tjele, Viborg, Denmark) to control and record internal water velocity and dissolved oxygen. Water temperature was maintained at $16.4 \pm 0.9^{\circ} \mathrm{C}$ and light intensity at $\sim 140 \mathrm{Lx}$ at the surface of the swimming tunnel. One hundred twenty-seven asp juveniles from the four treatment groups ( $30 \mathrm{SWNC}, 32 \mathrm{SWC}, 29 \mathrm{FWNC}, 36 \mathrm{FWC})$ were used in swimming tests 
after $24 \mathrm{~h}$ without feeding. Fish were selected from the experimental groups on a rotational basis to minimize possible additional growth between groups and temporal differences in measurements. For each measurement, individual fish were netted and immediately transferred to the swimming tunnel where they were allowed to acclimate for 25 min at a water flow velocity of $5 \mathrm{~cm} \times \mathrm{s}^{-1}$. The initial velocity of the experiment was maintained

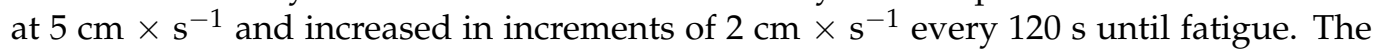
swimming test was terminated when the fish remained at the back grid for more than $10 \mathrm{~s}$ and did not respond to external stimuli.

Asp juveniles critical swimming speed $\left(\mathrm{U}_{\text {crit }}, \mathrm{cm} \times \mathrm{s}^{-1}\right)$ was calculated [54]:

$$
\mathrm{U}_{\text {crit }}=\mathrm{U}_{\max }+\left(\mathrm{T}_{\max } / \mathrm{T}_{\text {interval }} \times \mathrm{U}_{\text {interval }}\right)
$$

where $U_{\max }$ is the highest velocity recorded at fatigue $\left(\mathrm{cm} \times \mathrm{s}^{-1}\right)$; $\mathrm{U}_{\text {interval }}$ is velocity interval $\left(2 \mathrm{~cm} \times \min ^{-1}\right)$; $\mathrm{T}_{\max }$ is time until fatigued velocity; and $\mathrm{T}_{\text {interval }}$ is the whole time interval (60 s).

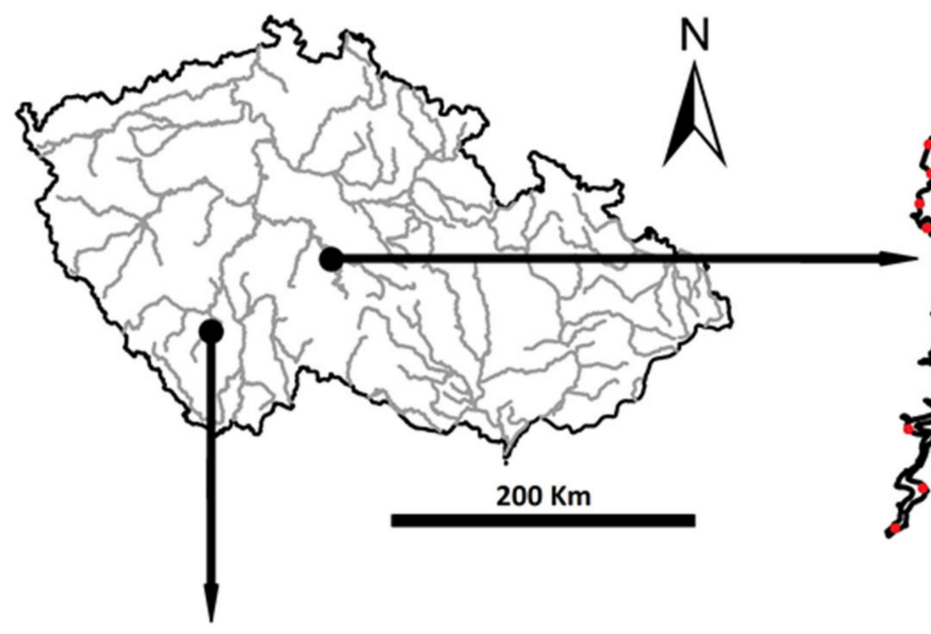

\section{Scheme of pond mesocosm experiment}

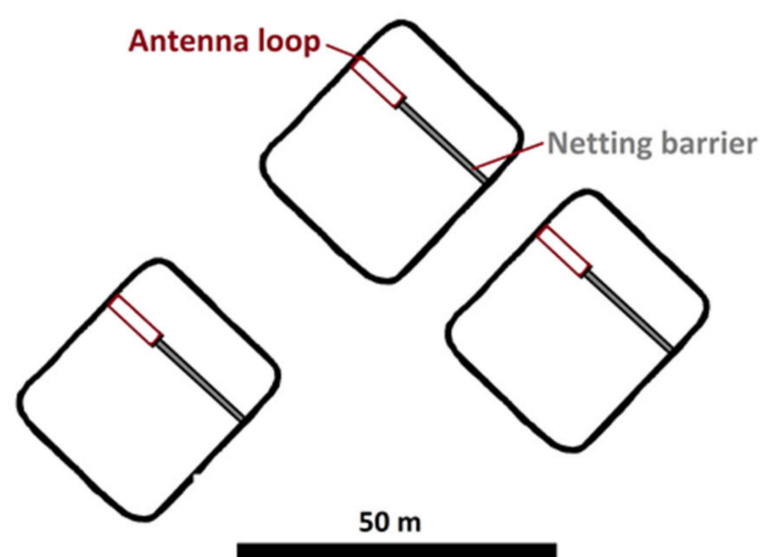

\section{Želivka Reservoir}

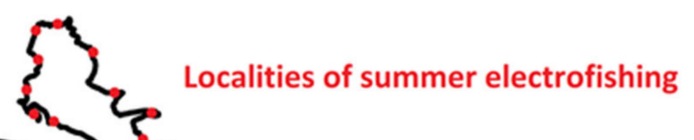

Figure 2. Sampled sites during the 2020 and 2021 summer survey for the survival of trained groups of stocked asp (Leuciscus aspius) in the Želivka Reservoir and scheme of pond mesocosm experiment setup with antenna array installation. Altogether, 1800 asp were used in pond mesocosm experiment (150 individuals from each of the four treatment groups stocked in each pond). 


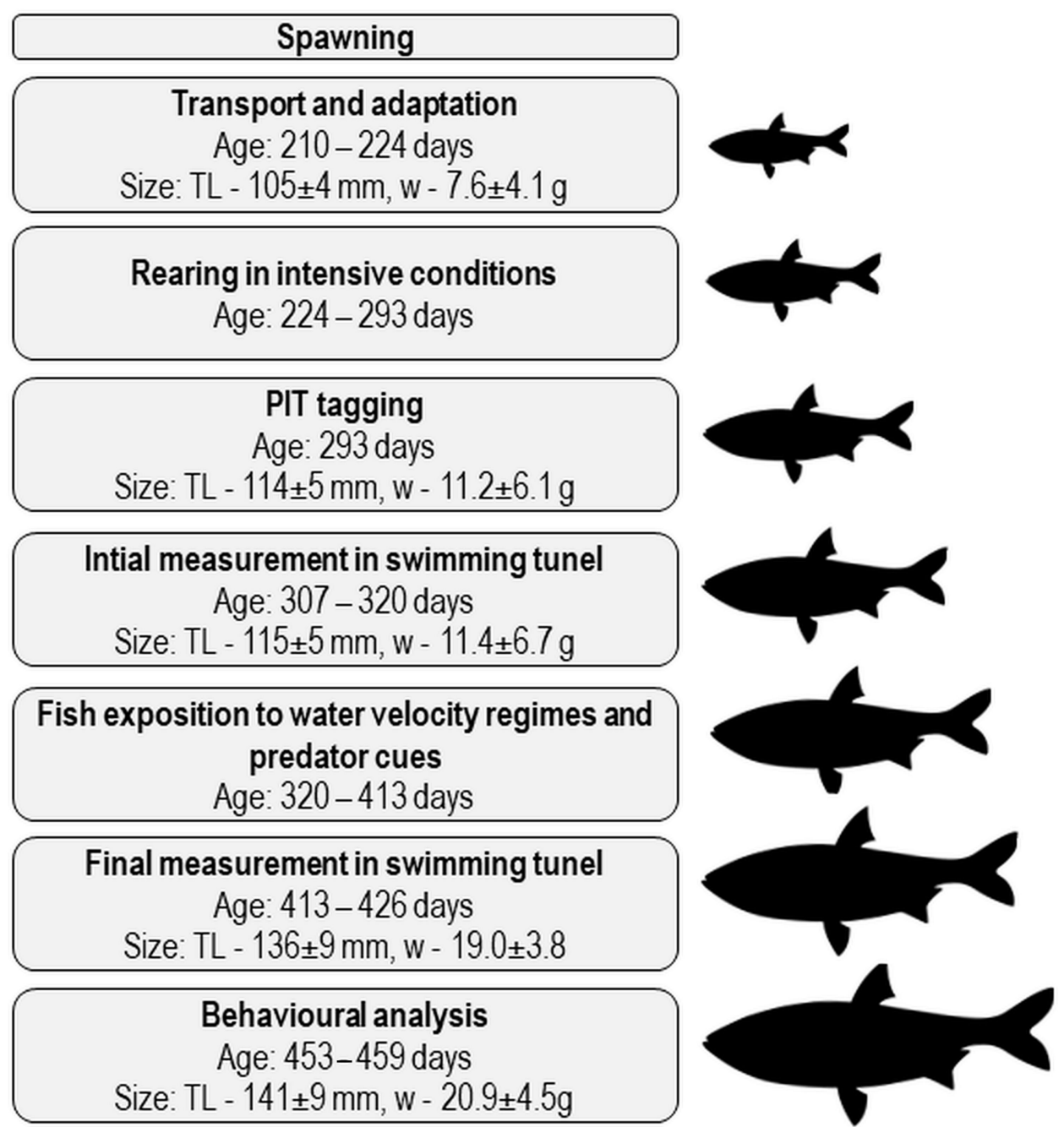

Figure 3. Phases of experimental rearing of asp for laboratory evaluation of fish performance after aquaculture treatment. Fish were kept at density of 275 individuals per tank. At the phase of PIT tagging, 40 randomly selected individuals were chosen per treatment and PIT tagged. Standard deviation is indicated after \pm sign.

\subsubsection{Reaction to Predator Chemical Cues}

To verify whether asp respond to predator chemical cues and are able to conceal their presence under perceived risk of predation, an experiment on behavioral change of asp was conducted after the introduction of predator chemical cues. We also tested whether responses differed between distinctly conditioned experimental groups. For the behavioral analysis of the reaction to predator chemical cues, we used thirty-three individuals per experimental group in eleven replicates ( 3 asp per tank for each test). Asp were gently netted from rearing tanks and placed in 8 round white test tanks ( 3 fish per tank; $\mathrm{H} \times \mathrm{D}=53 \times 68 \mathrm{~cm}$ ) to acclimate for one day (water temperature $17.1 \pm 1.0^{\circ} \mathrm{C}$, oxygen saturation $\geq 90 \%$, pH $7.3 \pm 0.5$ ). After overnight acclimation, the activity and interactions between 3 fish were videotaped (DS-2CD2043G0-I camera type, Hikvision, Hangzhou, China) for $20 \mathrm{~min}$ (10 min during the introduction of $1 \mathrm{~L}$ of dechlorinated water, and $10 \mathrm{~min}$ after the introduction of $1 \mathrm{~L}$ of predator chemical cues). The introduction of water in the tank lasted one minute. An aeration stone was placed on the side of the tank to facilitate chemical cues dispersion. The test with methylene blue showed dispersal within one minute of introduction. After each test, the water in the experimental tanks was thoroughly rinsed with tap water and refilled with dechlorinated aged tap water. Swimming activity of the shoal (sum of the number of grid crosses of each individual), shoaling index (number 
of fish swimming within one body length of each other), and number of startle responses (fast swimming events of any fish from the shoal) were evaluated for each 10-min section of the video (Supplementary Figure S1) [26].

\subsection{Data Preparation and Analysis}

\subsubsection{Pond Mesocosm Experiment}

The survival of asp after stocking was evaluated using a generalized linear mixed model fitted with a maximum likelihood model with a binary response $(0$ or 1$)$ in lme4 package [55]. The dependent variables were fish condition and treatment group (SWNC, SWC, FWNC, FWC) and the random intercept of the pond identity. An alternative model that included individual fish length and condition was excluded due to higher model complexity (AIC 1745.4 vs. 1747.4) and the nonsignificant effect of fish length tested using package glmmTMB [56]. The effect of treatment group and pond on fish growth after introduction of northern pike in ponds was tested by nested analysis of variance (ANOVA). Differences between groups were examined using multiple post hoc Tukey tests.

\subsubsection{Reservoir Stocking Experiment}

The list of recaptured asp was merged with the list of reared individuals by individual fish code, and growth was calculated by the difference between the initial and final fish SL. The list of detections from passive telemetry arrays was merged with the list of reared individuals by individual fish code to determine which stocked fish were detected by passive telemetry during the 2021 spring survey. Individuals that were simultaneously detected and captured by electrofishing were removed from the telemetry dataset because length information was missing from the passive telemetry dataset compared to the captured fish. Data sets were processed using the data.table, lubridate, and dplyr packages in $\mathrm{R}$ software [57-59].

To test whether detection probability depends on direct predation exposure (aquaculture treatment and transport to Želivka Reservoir vs. aquaculture treatment, northern pike predation for two months in the pond mesocosm experiment and then transport to Želivka Reservoir) and fish condition, a General Additive Model (GAM) was constructed with the dependent variable captured (levels True, False), treatment (SWNC, SWC, FWNC, FWC) and real predation (True-pond mesocosm experiment, False-direct transport to the reservoir from aquaculture). The model included an interaction between the factor of aquaculture training and real predation. The package mgcv was used to construct the model [60].

\subsubsection{Laboratory Assays on Conditioned Fish}

Normality and homoscedasticity assumptions were checked by Shapiro-Wilk and Levene's tests before conducting parametric tests, and nonparametric equivalent tests were chosen where appropriate (Supplementary Table S1). Whether the treatment groups (SWNC, SWC, FWNC, FWC) differed in their swimming performance was tested using the final critical speed in body lengths $\times \mathrm{s}^{-1}$ and the difference between initial and final values using a one-way ANOVA. A series of Bonferroni corrected Wilcoxon signed-rank tests was run to compare asp general behavior between those experimental groups where chemical predator cues were present (SWC and FWC) with the corresponding control groups (SWNC and FWNC). A Friedman test was used to test whether the reaction to predator chemical cues differed among the treatment groups. Data sets were processed using the data table, lubridate, and dplyr packages in R software [57-59] and visualization with package ggplot2 [61]. 


\section{Results}

\subsection{Pond Mesocosm Experiment}

Of the 600 fish introduced in each of the ponds, northern pike consumed an average of $121 \pm 24$ SD fish per pond in the two months, resulting in average mortality of two fish per day per pond. A general linear mixed effects model explaining survival probability with dependent variables of fish condition, predator chemical cues treatment, water velocity treatment, and pond random effect showed no effect of aquaculture conditioning on fish survival (Table 1). Type-III ANOVA did not show any significance among treatments (ANOVA: $\left.\chi^{2}(3,1795)=3.389, p=0.336\right)$ and condition factor $\left(\right.$ ANOVA: $\chi^{2}(1,1795)=0.982$, $p=0.322$ ) on fish survival. Survival curves for each treatment group showed similar trends, and their standard deviations overlapped during the two-month experiment (Figure 4).

Table 1. Parametric coefficient of the general linear mixed effects model of fish survival in pond mesocosm experiment under four treatment conditions: SWNC-standing water and no cues; FWNC-fluvial water and no cues; SWC-standing water and chemical cues; FWC-fluvial water and chemical cues.

\begin{tabular}{ccccc}
\hline & Estimate & Standard Error & Z Value & $p$ Value \\
\hline Intercept & 2.553 & 0.855 & 2.986 & 0.003 \\
Condition & -0.865 & 0.648 & -1.334 & 0.182 \\
SWNC & 0.010 & 0.175 & 0.059 & 0.953 \\
SWC & 0.145 & 0.179 & 0.812 & 0.417 \\
FWNC & -0.163 & 0.168 & -0.968 & 0.333 \\
\hline
\end{tabular}

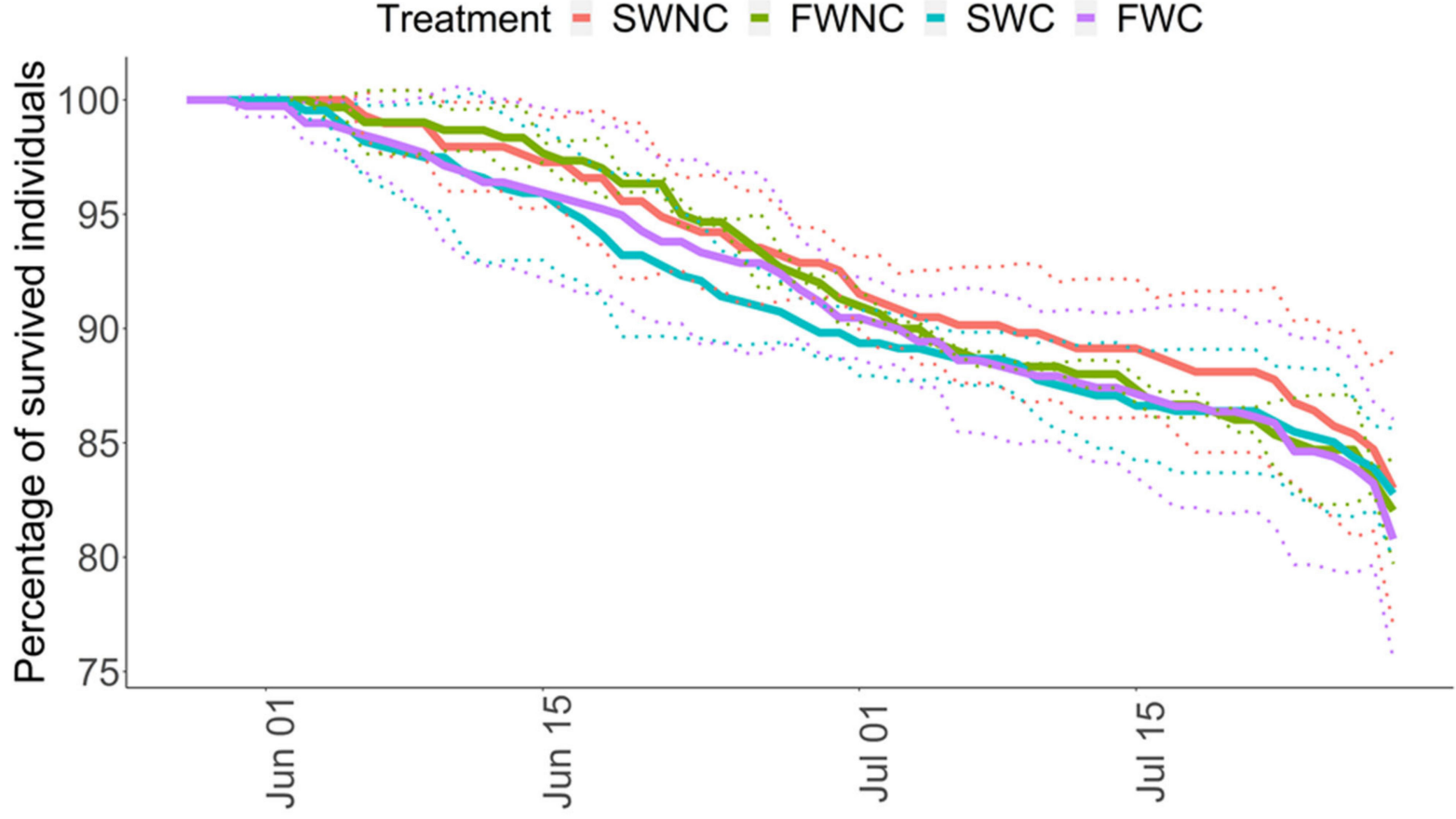

Figure 4. Survival rates of the four treatment groups of asp (Leuciscus aspius) in the semi-natural conditions predated by northern pike (Esox lucius). Conditioning involved the following treatments: SWNC-standing water and no cues; FWNC-fluvial water and no cues; SWC-standing water and chemical cues; FWC-fluvial water and chemical cues. The solid lines represent the mean of the three replicates and the dotted lines represent the standard deviation for each treatment. 
Fish treatment in the aquaculture had a significant effect on growth in the pond mesocosm experiment (ANOVA: $\mathrm{F}(3,1420)=3.887, p=0.009)$. Fish had an average growth increment of $23 \pm 25$ (mean $\pm \mathrm{SD}$ ) $\mathrm{mm}$. The growth of the SWC group was significantly lower than that of the FWC $(p=0.009)$ and FWNC $(p=0.04)$ groups, while the other combinations of treatment groups did not differ significantly (Figure 5). Fish grew significantly differently in the three ponds (ANOVA: $F(3,1420)=202.9, p<0.001)$ with significant post hoc Tukey's comparison for all combinations $(p<0.001)$, indicating unequal conditions in the ponds (Figure 5) due to the proliferation of the topmouth gudgeon Pseudorasbora parva - prey fish for asp-in two of three ponds. Based on the number of detections per fish when moving from one side of the pond to the other, the activity of fish from the treatment groups in the three ponds did not differ significantly (ANOVA: $\mathrm{F}(3,1420)=0.246, p=0.865$; Figure 6$)$.

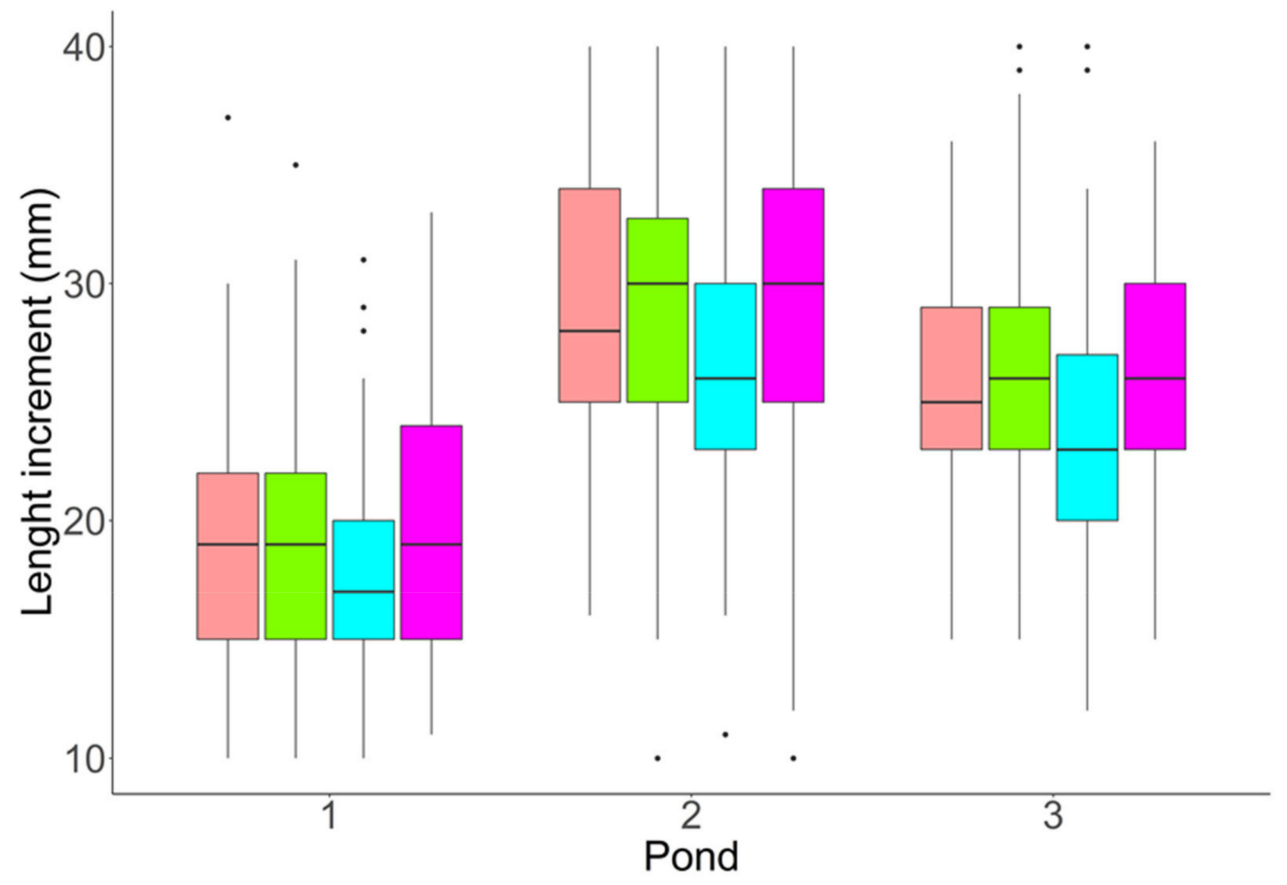

Treatment

自 SWNC

自 FWNC SWC

FWC

Figure 5. Growth increments of the four trained groups of asp (Leuciscus aspius) in the semi-natural conditions predated by northern pike (Esox lucius). Conditioning involved the following treatments: SWNC-standing water and no cues; FWNC-fluvial water and no cues; SWC-standing water and chemical cues; FWC-fluvial water and chemical cues. The thick line represents the median, the box represents $50 \%$ of interquartile range, and whiskers outer $25 \%$ of interquartile range excluding outliers.

\subsection{Reservoir Stocking Experiment}

A total of 52 asp were detected in the Želivka Reservoir (aquaculture groups: SWNC21, SWC-10, FWNC-10, FWC-11) and the effect of aquaculture treatment was not significant in the GAM model $\left(\chi^{2}=5.174, \mathrm{DF}=3, p=0.160\right)$ with $\mathrm{R}^{2}=0.004$ and $16.7 \%$ explained variance. However, there was a significant effect of exposure to true predation: the fish that went from aquaculture training to the pond mesocosm experiment with northern pike and then transported to the Želivka Reservoir were significantly more likely to be detected than those that went directly to the large field experiment. Of detected fish, $0.49 \%$ (30 fish from treatment) were transported directly to the reservoir, while $1.54 \%$ of detected fish (22 fish from treatment) were from the direct predation treatment in the pond mesocosms $\left(\chi^{2}=8.371, \mathrm{DF}=1, p=0.004\right)$. The interaction between aquaculture treatment and predation exposure was not significant $\left(\chi^{2}=4.188, \mathrm{DF}=3, p=0.241\right)$. Fish condition had no significant effect on fish survival $\left(\chi^{2}=0.063, \mathrm{DF}=1, p=0.802\right)$. Of the 52 detected asp, 13 asp were captured during the 2020 summer survey, 38 were captured or detected during the 2021 spring survey ( 29 by electrofishing and 19 by telemetry, with 10 fish 
detected by both methods), and only one individual was captured during the 2021 summer survey. While 12 individuals were captured from aquaculture in 2020 and only one was captured from aquaculture and the additional true predation treatment, the true predation treatment predominated in captures in 2021 (21 vs. 18). Evaluation of the growth of 42 recaptured fish by electrofishing by ANOVA showed no effect of aquaculture treatment $(\mathrm{F}$ $(3,34)=2.4, p=0.086)$, and no effect of real predation $(\mathrm{F}(1,34)=3.250, p=0.080)$ and no interaction between treatment and real predation $(\mathrm{F}(3,34)=0.156, p=0.925)$.

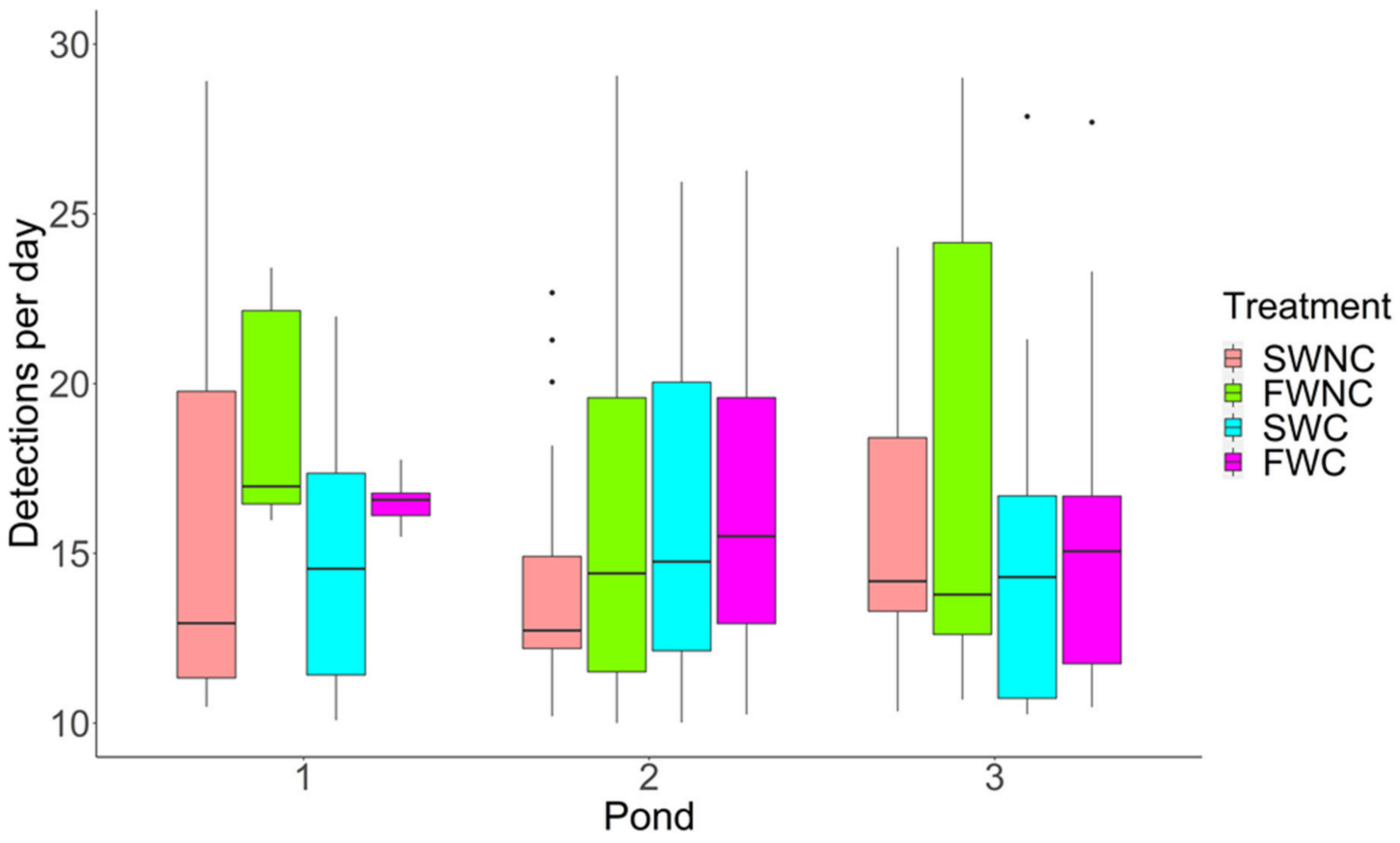

Figure 6. Activity (number of crossings from one section of the pond to another) of the four trained groups four groups of asp (Leuciscus aspius) in the semi-natural conditions predated by northern pike (Esox lucius). Conditioning involved the following treatments: SWNC-standing water and no cues; FWNC-fluvial water and no cues; SWC-standing water and chemical cues; FWC-fluvial water and chemical cues. The thick line represents the median, the box represents $50 \%$ of interquartile range, and whiskers outer $25 \%$ of interquartile range excluding outliers.

\subsection{Laboratory Assays on Conditioned Fish}

During the two-month preparation of the fish, they gained an average of $25 \pm 5 \mathrm{~mm}$ SL and $10 \pm 3 \mathrm{~g}$ in weight. Their condition factor after training was $1.3 \pm 0.1$. Their final swimming speed $\mathrm{U}_{\text {crit }}$ expressed in body lengths $\times \mathrm{s}^{-1}$ did not differ significantly among groups in final values (ANOVA: $\mathrm{F}(3,123)=0.785, p=0.504)$, nor did the relative difference from individual baseline after two months of training (ANOVA: $\mathrm{F}(3,123)=0.253, p=0.858$; Supplementary Figure S2).

In the experimental assessment of fish behavioral response to the addition of predator chemical cues, swimming activity increased significantly between the control and experimental treatments (Wilcoxon signed-rank test $(W): Z=296.5, p=0.042$; Figure 7). Furthermore, the shoaling index also increased significantly in the experimental treatment (W: $Z=131.5, p=0.045$; Figure 7). The number of startle responses did not increase significantly between the control and experimental treatments with predator chemical cues (W: $\mathrm{Z}=274.5, p=0.212)$. The aquaculture conditioning did not significantly alter the behavior to predator chemical cues for any parameter (Friedman test: $\chi^{2}(3)=0.491$, $p=0.921 ; \chi^{2}(3)=0.780, p=0.854$ and $\chi^{2}(3)=3.699, p=0.296$, respectively). 

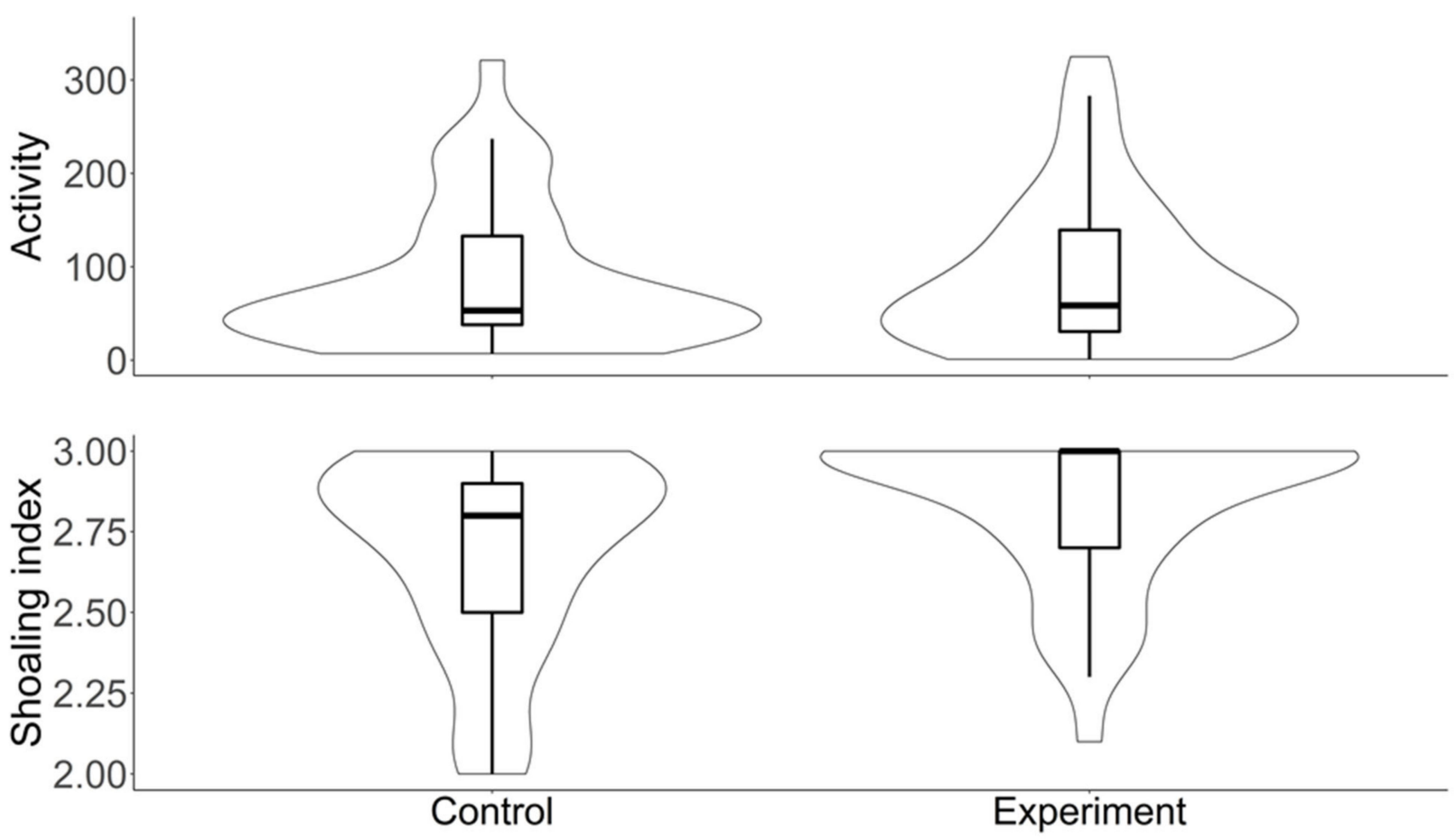

Figure 7. The comparison between the asp (Leuciscus aspius) activity and shoaling index between the control (addition of dechlorinated water) and the experimental treatment (addition of predator chemical cues). The boxes represent upper and lower quartiles; the thick lines represent the medians and the whiskers represent 1.5 times the interquartile range. The violin plot represents the data distribution as a probability density function.

\section{Discussion}

The main objective of the study was to test whether training of fish in aquaculture conditions may ease their transition in the novel environment and reduce the often high mortality rates of fish after stocking. However, we found no significant effect of aquaculture conditioning on fish survival in the wild. On the other hand, aquaculture-reared fish exposed to direct predators in pond mesocosms for two months survived three times better than their aquaculture-reared counterparts after stocking in the large reservoir. This suggests that the real threat of predation in the ponds improved survival in the wild (and to a lesser extent, individuals with poor predator avoidance were removed during treatment). Despite the $21 \%$ loss of aquaculture fish during this experiment, exposure of the fish to predators prior to their release had a positive effect on their subsequent survival in the wild, given that the detection rate was nearly 2.5 times higher for the trained fish.

Fish conditioned for predator image recognition in aquaculture often do not survive better in the wild [29,62]. For instance, Atlantic salmon (Salmo salar) were conditioned to recognize odor of northern pike, but the conditioned group did not differ in survival from the control group [62]. The reason why the theory often fails when antipredation conditioning is applied to large-scale breeding and stocking programs may be that the benefits of antipredation treatment are greatest only in the first few days after fish release [29]. After a few days from stocking, acquired predator recognition will likely occur in the post-release environment due to perceived attacks on fish conspecifics [63,64], especially in shoaling fish such as the juvenile asp used in our study [50]. Due to the relatively low predation rate in the pond mesocosms (an average of two fish per day), the results of the conditioning were not visible in the ponds even in the first few days after release. For instance, predation pressure by five different predators on stocked largemouth bass (Micropterus salmoides) resulted in a mortality rate of $27 \%$ in the first $12 \mathrm{~h}$ after stocking [23]. It is possible that the species selected for this study is not as vulnerable to predation as other species commonly stocked by fisheries, and therefore, the results of conditioning are 
not as obvious. However, asp seems to be positively selected as a prey fish by at least some predators such as European catfish (Silurus glanis) [65], although few data are available on this topic. Alternatively, as suggested by Brown and colleagues, aquaculture conditioning is not intensive enough compared to other needs of fish in aquaculture (food competition, hierarchy establishment) to sufficiently alter fish behavior after stocking in the wild [29]. Another important issue that must be highlighted is that the survival of stocked fish is also dependent on the predator density in the lake and other factors, so the efficiency of training is probably dependent on a multitude of factors that are virtually impossible to be quantified in large-scale experiments.

In the pond mesocosm experiment, an average of five northern pike individuals was stocked in ponds, corresponding to an abundance of over 80 northern pike and over 60 $\mathrm{kg}$ of biomass per ha. Despite the high pike density in the pond environment [66], the mortality rate of asp was not high. On the other hand, direct predator conditioning in the ponds was probably intense due to the high encounter rates between predator and prey in the small space of the pond. Although surviving asp from the pond mesocosms transported to the reservoir represented only about $20 \%$ of the total stocked individuals, the number of recaptured fish in 2021 already exceeded that of the aquaculture-only conditioned groups. This suggests that the numerical losses of fish during direct predator conditioning may pay off in the long-term survival of the stocked fish. More research is needed to verify this approach as profitable. In 2021, the fish were two years old and will be mature in two to three years. Their detection by passive telemetry arrays during reproductive migration $[67,68]$ may shed more light on the survival among groups and verify the current significance of the data. Assessing survival to adulthood by detecting spawning individuals could therefore be more accurate than the methods used to collect the currently available data. Another tool that can be applied to identify the survival rate of stocked individuals is the analysis of the fish scale and otolith shape and chemistry, which are effective tools to determine the fish origin [12,69].

The quality of fish reared in hatcheries may be improved, for example, by more complex structural conditions of the tank [70,71] and by forcing fish in aquaculture to swim more, which has often a positive effect on their swimming abilities [72,73]. Fish trained in fluvial conditions may move more than conspecifics trained in standing water after their release [72], but higher swimming activity may also potentially increase the encounter rate with predators $[43,74,75]$. The potential effect of increased activity was not significant in the pond experiment, and such an effect was only evident in Pond 1 . The ponds differed visually in turbidity, and Pond 1 was very clear with dense macrophyte growth compared to Ponds 2 and 3, and this effect could have led to different activities of fish in the ponds. Here we must also acknowledge that the measurement of activity in the mesocosm experiment was only an approximation, and the number of passes between pond sections may not reflect differences in activity at the fine scale. Further research on the relationship between swimming capacity training and the relationship with predation is needed to reach conclusive results. Research tools such as 2D or 3D acoustic telemetry may be better suited to quantify activity differences among trained groups [76].

Fish growth in the pond mesocosm experiment differed between treatments, with training on predator chemical cues and standing water resulting in slower growth in comparison with the other three treatments. Predation risk can sometimes lead to behavioral responses that have greater consequences for the animal than the actual (and relatively small) risk of being predated $[77,78]$. Therefore, it is possible that the SWC group invested so much energy in avoiding predation due to predator chemical cues that were the only stimuli apart from feeding during aquaculture preparation that this limited their foraging activity in the ponds. The trend of lower growth rate was apparent in all treatments, despite different turbidity conditions potentially affecting food intake in combination with predation risk [78].

Fish condition during the stocking is assumed to be especially important due to loss of weight in the first days after release [42,45]. Therefore, it is relatively surprising that the 
condition was not significant in both the pond mesocosm and reservoir experiments. On the other hand, food distribution during the aquaculture rearing period was uniform, and fish were fed ad libitum, so condition did not vary greatly between individuals.

Fish from fluvial conditions were not significantly better than their conspecifics from standing water in the swimming tunnel. This could be due to the possibility that fish actively avoided the fast current in the rearing tank and the actual exposure to a high flow was not that different from the control group. The other option is that asp was stressed during the exercise and many fish performed very poorly in their test despite the rheophilic nature of this fish [79]. Because the number of fish per treatment used for testing was not that large, it is possible that the differences among treatments would be significant with a larger sample size. Finally, the fish were trained to swim in a still relatively low current $\left(20 \mathrm{~cm} \times \mathrm{s}^{-1}\right)$ during the training period, which may not have been sufficiently high to improve their maximum swimming speeds tested in the laboratory.

Asp responded to the introduction of predator chemical cues by increasing their shoaling index - a typical anti-predator response-and increasing their activity. In many cases, fish tend to reduce their swimming activity more when they sense the threat of predators [26]. As a fish oriented in the open water and not being associated with underwater structures [80], asp may rely more on escape options than on reducing its movement.

While this study provides some new insights into improving the survival of fish bred in aquaculture for stocking in the wild, there is an avenue for future research in this field. The finding that fish exposed directly to the predator (northern pike) for two months survived significantly better than fish raised in aquaculture and released in the wild can be extended through future studies. Further investigation can be conducted to determine optimal time and predator and prey densities to expose fish to direct predation. It is possible that shortening the two-month period used here could reduce losses of aquaculture-raised fish while maintaining similar survival chances in the wild. Additionally, less valuable prey fish can be added to a conditioning setup to reduce the losses on targeted fish species.

Supplementary Materials: The following are available online at https://www.mdpi.com/article/10 .3390/su132413936/su132413936/s1, Figure S1: Schematic drawings of behavioral test; Figure S2: The absolute performance in body lengths $\times \mathrm{s}^{-1}$ and relative performance the improvement before and after conditioning period of asp (Leuciscus aspius); Table S1: Summary of statistical tests used in the study.

Author Contributions: M.Š., D.B., S.T., V.S., Y.S. and P.P. participated in the aquaculture and field work; M.Š., P.P. and V.S. designed the study; M.Š., V.S., Y.S. and P.B. prepared data for the analysis; P.B., A.T.S. and M.Š. conducted the statistical analysis; M.Š. and V.S. wrote the first draft. All authors have read and agreed to the published version of the manuscript.

Funding: This research was supported by the project QK1920326-"Aquaculture of rheophilous fish" as well as project supported by Ministry of Education, Youth and Sports of the Czech Republic [LM2018099].

Institutional Review Board Statement: The field sampling methods and experimental protocols used in this study were performed in accordance with the guidelines and permission from the Ministry of the Environment of the Czech Republic (No. OZPZ 2973/2016 and OZPZ 260/2018) and approved by the Experimental Animal Welfare Commission of Biology Centre of the Czech Academy of Sciences.

Informed Consent Statement: Not applicable.

Data Availability Statement: The data presented in this study are available on request from the corresponding author.

Acknowledgments: We thank Aneta Schreinerová, Tomáš Kolařík, Tomáš Minařík, Tram Nguyen Thi, Tran Quang Hung and Pavel Šablatura for their assistance during laboratory and fieldwork.

Conflicts of Interest: The authors declare no competing financial interests. 


\section{References}

1. Olden, J.D.; Poff, N.L.R.; Douglas, M.R.; Douglas, M.E.; Fausch, K.D. Ecological and evolutionary consequences of biotic homogenization. Trends Ecol. Evol. 2004, 19, 18-24. [CrossRef]

2. Chong, V.C.; Lee, P.K.Y.; Lau, C.M. Diversity, extinction risk and conservation of Malaysian fishes. J. Fish Biol. 2010, 76, 2009-2066. [CrossRef]

3. Rahel, F.J. Homogenization of Freshwater Faunas. Annu. Rev. Ecol. Syst. 2002, 33, 291-315. [CrossRef]

4. Grill, G.; Lehner, B.; Thieme, M.; Geenen, B.; Tickner, D.; Antonelli, F.; Babu, S.; Borrelli, P.; Cheng, L.; Crochetiere, H.; et al. Mapping the world's free-flowing rivers. Nature 2019, 569, 215-221. [CrossRef]

5. $\quad$ Fitzgerald, D.B.; Tobler, M.; Winemiller, K.O. From richer to poorer: Successful invasion by freshwater fishes depends on species richness of donor and recipient basins. Glob. Chang. Biol. 2016, 22, 2440-2450. [CrossRef] [PubMed]

6. Baum, J.K.; Worm, B. Cascading top-down effects of changing oceanic predator abundances. J. Anim. Ecol. 2009, 78, 699-714. [CrossRef]

7. Bartoň, D.; Blabolil, P.; Sajdlová, Z.; Veǰrík, L.; Souza, A.T.; Kubečka, J.; Šmejkal, M. Effects of hydropeaking on the attached eggs of a rheophilic cyprinid species. Ecohydrology 2021, 14, e2280. [CrossRef]

8. Liu, X.; Qin, J.; Xu, Y.; Ouyang, S.; Wu, X. Biodiversity decline of fish assemblages after the impoundment of the Three Gorges Dam in the Yangtze River Basin, China. Rev. Fish Biol. Fish. 2019, 29, 177-195. [CrossRef]

9. Moyle, P.B.; Williams, J.E. Biodiversity Loss in the Temperate Zone: Decline of the Native Fish Fauna of California. Conserv. Biol. 1990, 4, 275-284. [CrossRef]

10. Arthington, A.H.; Dulvy, N.K.; Gladstone, W.; Winfield, I.J. Fish conservation in freshwater and marine realms: Status, threats and management. Aquat. Conserv. Mar. Freshw. Ecosyst. 2016, 26, 838-857. [CrossRef]

11. Sayer, C.D.; Copp, G.H.; Emson, D.; Godard, M.J.; Zięba, G.; Wesley, K.J. Towards the conservation of crucian carp Carassius carassius: Understanding the extent and causes of decline within part of its native English range. J. Fish Biol. 2011, 79, $1608-1624$. [CrossRef]

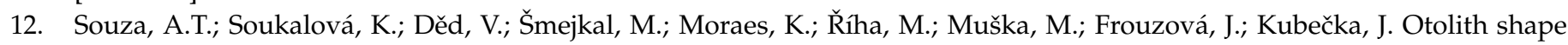
variations between artificially stocked and autochthonous pikeperch (Sander lucioperca). Fish. Res. 2020, 231. [CrossRef]

13. Eby, L.A.; Roach, W.J.; Crowder, L.B.; Stanford, J.A. Effects of stocking-up freshwater food webs. Trends Ecol. Evol. 2006, 21, 576-584. [CrossRef] [PubMed]

14. Johnsson, J.I.; Brockmark, S.; Näslund, J. Environmental effects on behavioural development consequences for fitness of captivereared fishes in the wild. J. Fish Biol. 2014, 85, 1946-1971. [CrossRef] [PubMed]

15. Gil, M.M.; Palmer, M.; Grau, A.; Deudero, S.; Alconchel, J.I.; Catalán, I.A. Adapting to the wild: The case of aquaculture-produced and released meagres Argyrosomus regius. J. Fish Biol. 2014, 84, 10-30. [CrossRef] [PubMed]

16. Araki, H.; Schmid, C. Is hatchery stocking a help or harm?: Evidence, limitations and future directions in ecological and genetic surveys. Aquaculture 2010, 308, S2-S11. [CrossRef]

17. Saloniemi, I.; Jokikokko, E.; Kallio-Nyberg, I.; Jutila, E.; Pasanen, P. Survival of reared and wild Atlantic salmon smolts: Size matters more in bad years. ICES J. Mar. Sci. 2004, 61, 782-787. [CrossRef]

18. D'Anna, G.; Giacalone, V.M.; Vega Fernández, T.; Vaccaro, A.M.; Pipitone, C.; Mirto, S.; Mazzola, S.; Badalamenti, F. Effects of predator and shelter conditioning on hatchery-reared white seabream Diplodus sargus (L., 1758) released at sea. Aquaculture 2012, 356-357, 91-97. [CrossRef]

19. Ferrari, M.C.O.; Wisenden, B.D.; Chivers, D.P. Chemical ecology of predator-prey interactions in aquatic ecosystems: A review and prospectus. Can. J. Zool. 2010, 88, 698-724. [CrossRef]

20. Rahman, M.M. Role of common carp (Cyprinus carpio) in aquaculture production systems. Front. Life Sci. 2015, 8, 399-410. [CrossRef]

21. Diana, J.S. Aquaculture Production and Biodiversity Conservation. Bioscience 2009, 59, 27-38. [CrossRef]

22. Baras, E.; Kestemont, P.; Mélard, C. Effect of stocking density on the dynamics of cannibalism in sibling larvae of Perca fluviatilis under controlled conditions. Aquaculture 2003, 219. [CrossRef]

23. Buckmeier, D.L.; Betsill, R.K.; Schlechte, J.W. Initial Predation of Stocked Fingerling Largemouth Bass in a Texas Reservoir and Implications for Improving Stocking Efficiency. N. Am. J. Fish. Manag. 2011, 25, 652-659. [CrossRef]

24. Thorstad, E.B.; Uglem, I.; Finstad, B.; Chittenden, C.M.; Nilsen, R.; Økland, F.; Bjørn, P.A. Stocking location and predation by marine fishes affect survival of hatchery-reared Atlantic salmon smolts. Fish. Manag. Ecol. 2012, 19, 400-409. [CrossRef]

25. Wisenden, B.D. Olfactory assessment of predation risk in the aquatic environment. Philos. Trans. R. Soc. Lond. B Biol. Sci. 2000, 355, 1205-1208. [CrossRef]

26. Šmejkal, M.; Ricard, D.; Sajdlová, Z.; Čech, M.; Vejřík, L.; Blabolil, P.; Vejříková, I.; Prchalová, M.; Vašek, M.; Souza, A.T.; et al. Can species-specific prey responses to chemical cues explain prey susceptibility to predation? Ecol. Evol. 2018. [CrossRef] [PubMed]

27. Mathis, A.; Smith, R.J.F. Chemical alarm signals increase the survival time of fathead minnows (Pimephales promelas) during encounters with northern pike (Esox lucius). Behav. Ecol. 1993, 4, 260-265. [CrossRef]

28. Chivers, D.P.; Smith, R.J.F. Fathead minnows, Pimephales promelas, acquire predator recognition when alarm substance is associated with the sight of unfamiliar fish. Anim. Behav. 1994, 48, 597-605. [CrossRef]

29. Brown, G.E.; Ferrari, M.C.O.; Chivers, D.P. Adaptive Forgetting: Why Predator Recognition Training Might Not Enhance Poststocking Survival. Fisheries 2013, 38, 16-25. [CrossRef] 
30. Greggor, A.L.; Price, C.J.; Shier, D.M. Examining the efficacy of anti-predator training for increasing survival in conservation translocations: A systematic review protocol. Environ. Evid. 2019, 8, 11. [CrossRef]

31. Zhou, C.; Xu, D.; Lin, K.; Sun, C.; Yang, X. Intelligent feeding control methods in aquaculture with an emphasis on fish: A review. Rev. Aquac. 2018, 10, 975-993. [CrossRef]

32. ̌̉íha, M.; Gjelland, K.Ø.; Děd, V.; Eloranta, A.P.; Rabaneda-Bueno, R.; Baktoft, H.; Vejřík, L.; Vejř́́ková, I.; Draštík, V.; Šmejkal, M.; et al. Contrasting structural complexity differentiate hunting strategy in an ambush apex predator. Sci. Rep. 2021, 11, 17472. [CrossRef] [PubMed]

33. Ivanova, S.V.; Johnson, T.B.; Metcalfe, B.; Fisk, A.T. Spatial distribution of lake trout (Salvelinus namaycush) across seasonal thermal cycles in a large lake. Freshw. Biol. 2021, 66, 615-627. [CrossRef]

34. Stejskal, V.; Matousek, J.; Sebesta, R.; Prokesova, M.; Vanina, T.; Podhorec, P. Prevalence of deformities in intensively reared peled Coregonus peled and comparative morphometry with pond-reared fish. J. Fish Dis. 2018, 41, 375-381. [CrossRef] [PubMed]

35. Bosakowski, T.; Wagner, E.J. Assessment of Fin Erosion by Comparison of Relative Fin Length in Hatchery and Wild Trout in Utah. Can. J. Fish. Aquat. Sci. 2011, 51, 636-641. [CrossRef]

36. Latremouille, D.N. Fin Erosion in Aquaculture and Natural Environments. Rev. Fish. Sci. 2010, 11, 315-335. [CrossRef]

37. Stejskal, V.; Policar, T.; Křišt'an, J.; Kouřil, J.; Hamáčková, J. Fin condition in intensively cultured Eurasian perch (Perca fluviatilis). J. Vertebr. Biol. 2011, 60, 122-128. [CrossRef]

38. Plaut, I. Effects of fin size on swimming performance, swimming behaviour and routine activity of zebrafish Danio rerio. J. Exp. Biol. 2000, 203, 813-820. [CrossRef]

39. Fu, C.; Cao, Z.-D.; Fu, S.-J. The effects of caudal fin loss and regeneration on the swimming performance of three cyprinid fish species with different swimming capacities. J. Exp. Biol. 2013, 216, 3164-3174. [CrossRef]

40. Härkönen, L.; Hyvärinen, P.; Paappanen, J.; Vainikka, A. Explorative behavior increases vulnerability to angling in hatchery-reared brown trout (Salmo trutta). Can. J. Fish. Aquat. Sci. 2014, 71, 1900-1909. [CrossRef]

41. Malavasi, S.; Georgalas, V.; Lugli, M.; Torricelli, P.; Mainardi, D. Differences in the pattern of antipredator behaviour between hatchery-reared and wild European sea bass juveniles. J. Fish Biol. 2004, 65, 143-155. [CrossRef]

42. Ersbak, K.; Haase, B.L. Nutritional Deprivation after Stocking as a Possible Mechanism Leading to Mortality in Stream-Stocked Brook Trout. N. Am. J. Fish. Manag. 1983, 3, 142-151. [CrossRef]

43. Hulthén, K.; Chapman, B.B.; Nilsson, P.A.; Hansson, L.-A.; Skov, C.; Brodersen, J.; Vinterstare, J.; Brönmark, C. A predation cost to bold fish in the wild. Sci. Rep. 2017, 7, 1239. [CrossRef] [PubMed]

44. Gunn, J.M.; McMurtry, M.J.; Bowlby, J.; Casselman, J.M.; Liimatainen, V.A. Survival and Growth of Stocked Lake Trout in Relation to Body Size, Stocking Season, Lake Acidity, and Biomass of Competitors. Trans. Am. Fish. Soc. 1987, 116, 618-627. [CrossRef]

45. Tatara, C.P.; Riley, S.C.; Scheurer, J.A. Growth, Survival, and Habitat Use of Naturally Reared and Hatchery Steelhead Fry in Streams: Effects of an Enriched Hatchery Rearing Environment. Trans. Am. Fish. Soc. 2011, 138, 441-457. [CrossRef]

46. Vašek, M.; Eloranta, A.P.; Vejříková, I.; Blabolil, P.; Říha, M.; Jůza, T.; Šmejkal, M.; Matěna, J.; Kubečka, J.; Peterka, J. Stable isotopes and gut contents indicate differential resource use by coexisting asp (Leuciscus aspius) and pikeperch (Sander lucioperca). Ecol. Freshw. Fish 2018, 27, 1054-1065. [CrossRef]

47. Vašek, M.; Vejřík, L.; Vejříková, I.; Šmejkal, M.; Baran, R.; Muška, M.; Kubečka, J.; Peterka, J. Development of non-lethal monitoring of stable isotopes in asp (Leuciscus aspius): A comparison of muscle, fin and scale tissues. Hydrobiologia 2016, 785, 327-335. [CrossRef]

48. Šmejkal, M.; Bartoň, D.; Brabec, M.; Sajdlová, Z.; Souza, A.T.; Moraes, K.R.; Soukalová, K.; Blabolil, P.; Veǰ̌ík, L.; Kubečka, J. Climbing up the ladder: Male reproductive behaviour changes with age in a long-lived fish. Behav. Ecol. Sociobiol. 2021, 75, 22. [CrossRef]

49. Šmejkal, M.; Ricard, D.; Vejř́́k, L.; Mrkvička, T.; Vebrová, L.; Baran, R.; Blabolil, P.; Sajdlová, Z.; Vejříková, I.; Prchalová, M.; et al. Seasonal and daily protandry in a cyprinid fish. Sci. Rep. 2017, 7, 4737. [CrossRef]

50. Blabolil, P.; Bartoň, D.; Halačka, K.; Kočvara, L.; Kolař́́k, T.; Kubečka, J.; Šmejkal, M.; Peterka, J. The fate of 0+ asp (Leuciscus aspius) after being stocked in a reservoir. Biologia 2020, 75, 989-996. [CrossRef]

51. Skov, C.; Brodersen, J.; Bronmark, C.; Hansson, L.-A.; Hertonsson, P.; Nilsson, P.A. Evaluation of PIT-tagging in cyprinids. J. Fish Biol. 2005, 67, 1195-1201. [CrossRef]

52. Hulthén, K.; Chapman, B.B.; Nilsson, P.A.; Hansson, L.A.; Skov, C.; Baktoft, H.; Brodersen, J.; Brönmark, C. Sex identification and PIT-tagging: Tools and prospects for studying intersexual differences in freshwater fishes. J. Fish Biol. 2014, 84, 503-512. [CrossRef] [PubMed]

53. Vollset, K.W.; Lennox, R.J.; Thorstad, E.B.; Auer, S.; Bär, K.; Larsen, M.H.; Mahlum, S.; Näslund, J.; Stryhn, H.; Dohoo, I. Systematic review and meta-analysis of PIT tagging effects on mortality and growth of juvenile salmonids. Rev. Fish Biol. Fish. 2020, 30, 553-568. [CrossRef]

54. Brett, J.R. The Respiratory Metabolism and Swimming Performance of Young Sockeye Salmon. J. Fish. Res. Board Canada 1964, 21, 1183-1226. [CrossRef]

55. Bates, D.; Mächler, M.; Bolker, B.; Walker, S. Fitting Linear Mixed-Effects Models Using lme4. J. Stat. Softw. 2015, 67, 1-48. [CrossRef] 
56. Brooks, M.E.; Kristensen, K.; van Benthem, K.J.; Magnusson, A.; Berg, C.W.; Nielsen, A.; Skaug, H.J.; Mächler, M.; Bolker, B.M. glmmTMB balances speed and flexibility among packages for zero-inflated generalized linear mixed modeling. $R J$. 2017, 9, 378-400. [CrossRef]

57. Dowle, M.; Srinivasan, A. Data.Table: Extension of 'Data.Frame'. R Package Version 1.14.2. 2021. Available online: https: / /CRAN.R-project.org/package=data.table (accessed on 15 December 2021).

58. Grolemund, G.; Wickham, H. Dates and Times Made Easy with lubridate. J. Stat. Softw. 2011, 40, 1-25. [CrossRef]

59. Wickham, H.; François, R.; Henry, L.; Müller, K. dplyr: A Grammar of Data Manipulation. R Package Version 1.0.7. 2021. Available online: https:/ /CRAN.R-project.org/package=dplyr (accessed on 15 December 2021).

60. Wood, S.N. mgcv: GAMs and generalized ridge regression for R. R News 2001.

61. Wickham, H. ggplot2: Elegant Graphics for Data Analysis; Springer: New York, NY, USA, 2016.

62. Hawkins, L.A.; Armstrong, J.D.; Magurran, A.E. A test of how predator conditioning influences survival of hatchery-reared Atlantic salmon, Salmo salar, in restocking programmes. Fish. Manag. Ecol. 2007, 14, 291-293. [CrossRef]

63. Berejikian, B.A.; Smith, R.J.F.; Tezak, E.P.; Schroder, S.L.; Knudsen, C.M. Chemical alarm signals and complex hatchery rearing habitats affect antipredator behavior and survival of chinook salmon (Oncorhynchus tshawytscha) juveniles. Can. J. Fish. Aquat. Sci. 2011, 56, 830-838. [CrossRef]

64. Brown, G.E.; Smith, R.J.F. Acquired predator recognition in juvenili rainbow trot (Oncorhynchus mykiss): Conditioning HatcheryReared Fish To Recognize Chemical Cues of a Predator. Can. J. Fish. Aquat. Sci. 1998, 55, 611-617. [CrossRef]

65. Vejř́ik, L.; Vejř́ková, I.; Blabolil, P.; Eloranta, A.P.; Kočvara, L.; Peterka, J.; Sajdlová, Z.; Chung, S.H.T.; Šmejkal, M.; Kiljunen, M.; et al. European catfish (Silurus glanis) as a freshwater apex predator drives ecosystem via its diet adaptability. Sci. Rep. 2017, 7, 15970. [CrossRef]

66. Rask, M.; Arvola, L. The biomass and production of pike, perch and whitefish in two small lakes in southern Finland. Ann. Zool. Fennici 1985, 22, 129-136.

67. Šmejkal, M.; Bartoň, D.; Děd, V.; Souza, A.T.; Blabolil, P.; Vejřík, L.; Sajdlová, Z.; Říha, M.; Kubečka, J. Negative feedback concept in tagging: Ghost tags imperil the long-term monitoring of fishes. PLoS One 2020, 15, e0229350. [CrossRef]

68. Šmejkal, M.; Souza, A.T.; Blabolil, P.; Bartoň, D.; Sajdlová, Z.; Vejřík, L.; Kubečka, J. Nocturnal spawning as a way to avoid egg exposure to diurnal predators. Sci. Rep. 2018, 8, 15377. [CrossRef] [PubMed]

69. Rashidabadi, F.; Abdoli, A.; Tajbakhsh, F.; Nejat, F.; Avigliano, E. Unravelling the stock structure of the Persian brown trout by otolith and scale shape. J. Fish Biol. 2019, 96, 307-315. [CrossRef]

70. Bergendahl, I.A.; Miller, S.; Depasquale, C.; Giralico, L.; Braithwaite, V.A. Becoming a better swimmer: Structural complexity enhances agility in a captive-reared fish. J. Fish Biol. 2017, 90, 1112-1117. [CrossRef]

71. Näslund, J.; Johnsson, J.I. Environmental enrichment for fish in captive environments: Effects of physical structures and substrates. Fish Fish. 2016, 17, 1-30. [CrossRef]

72. Anttila, K.; Jokikokko, E.; Erkinaro, J.; Järvilehto, M.; Mänttäri, S. Effects of training on functional variables of muscles in reared Atlantic salmon Salmo salar smolts: Connection to downstream migration pattern. J. Fish Biol. 2011, 78, 552-566. [CrossRef]

73. He, W.; Xia, W.; Cao, Z.D.; Fu, S.J. The effect of prolonged exercise training on swimming performance and the underlying biochemical mechanisms in juvenile common carp (Cyprinus carpio). Comp. Biochem. Physiol. Part A Mol. Integr. Physiol. 2013, 166, 308-315. [CrossRef]

74. Biro, P.A.; Post, J.R. Rapid depletion of genotypes with fast growth and bold personality traits from harvested fish populations. Proc. Natl. Acad. Sci. USA 2008, 105, 2919-2922. [CrossRef] [PubMed]

75. Zhou, L.-Y.; Yan, X.-Y.; Li, X.-M.; Fu, X.; Xia, J.-G.; Fu, S.-J. Effect of exercise training on swimming performance, survival under predation and hypoxia tolerance in an endangered fish species in China. Mar. Freshw. Behav. Physiol. 2019, 52, 67-82. [CrossRef]

76. Lennox, R.J.; Westrelin, S.; Souza, A.T.; Šmejkal, M.; Říha, M.; Prchalová, M.; Nathan, R.; Koeck, B.; Killen, S.; Jari, I.; et al. A role for lakes in revealing the nature of animal movement using high dimensional telemetry systems. Mov. Ecol. 2021, 9, 40. [CrossRef] [PubMed]

77. Lima, S.L. Nonlethal effects in the ecology of predator-prey interactions. Bioscience 1998, 48, 25. [CrossRef]

78. Figueiredo, B.R.S.; Mormul, R.P.; Chapman, B.B.; Lolis, L.A.; Fiori, L.F.; Benedito, E. Turbidity amplifies the non-lethal effects of predation and affects the foraging success of characid fish shoals. Freshw. Biol. 2016, 61, 293-300. [CrossRef]

79. Fredrich, F. Long-term investigations of migratory behaviour of asp (Aspius aspius L.) in the middle part of the Elbe River, Germany. J. Appl. Ichthyol. 2003, 19, 294-302. [CrossRef]

80. Šmejkal, M.; Prchalová, M.; Čech, M.; Vašek, M.; Říha, M.; Jůza, T.; Blabolil, P.; Kubečka, J. Associations of fish with various types of littoral habitats in reservoirs. Ecol. Freshw. Fish 2014, 23, 405-413. [CrossRef] 